\title{
1. Social security protection for informal economy workers: developing world perspectives
}

\section{Marius Olivier}

\section{INTRODUCTION}

Focusing primarily on informal economy workers in developing countries, this contribution critically reflects on, firstly, salient aspects of the conceptual and demographic framework relating to informal employment; secondly, the exclusion or limited application of social security for those who work in the informal economy; and, thirdly, a range of recent, innovative mechanisms to effect expansion of coverage regarding these workers, based on social security conceptual and instrumental innovation, and supported by a progressive appreciation of the social security values domain and human rights dispensation in developing countries. In the section preceding the conclusions, examples of coverage extension in four countries, that is, China, India, Tunisia and Ghana, are separately reflected on.

Different from what the position might be in the so-called developed economies, informal employment is not generally regarded as illegal or irregular in the developing world, but as a standard way of life and income-generation. Informal employment represents a significant share of non-agricultural employment in developing regions. The result is extremely low levels of social security coverage, both quantitatively and qualitatively. This flows from a variety of reasons, including restricted conceptual frameworks, absent or deficient institutional structures and instruments, inappropriate eligibility criteria, lack of or non-involvement of representative institutions, exclusionary contributory and benefit regimes, and limited administrative capacity and enforcement ability. Also, social insurance laws are restricted to those who work within the confines of the traditional employment relationship, who are employees in the narrow sense of the word, and who work for an identifiable and 
equally narrowly defined employer - thereby definitionally excluding most informal workers from protection. Finally, with some exceptions, international standards have limited impact on these workers.

And yet, especially in the last few decades, pronounced and unprecedented steps have been taken in several developing countries to extend social security coverage to informal workers. The contribution critically reflects on the rationale for and nature of these extension modalities. These developments have largely been informed by economic considerations and shifting social, cultural and conceptual perceptions; a new appreciation of the human rights debate in the provisioning of social security; and the social contract between the state/government and its citizens. Conceptual and regulatory adjustments in areas affecting the very notion and purpose of social security, the so-called contingencies covered by (traditional) social security, and some of the actors involved (e.g. a redefined understanding of "workers" and "employers") have been paramount. Also, there has been a dedicated construction of appropriate institutional frameworks, while new forms of representative structures have been operative in this domain.

These adjustments and developments challenge the traditional boundaries of the social security notion, aims, structures and mechanisms. The contribution adds to the developing scientific discourse on these matters, also by reflecting on the foundational values informing social security and alternative perspectives on social security.

\section{SIZE AND CHARACTERISTICS ${ }^{1}$}

In its recently published global overview of the magnitude of the informal economy, the International Labour Organization (ILO) indicates that two billion of the world's employed population aged 15 and over work informally, representing 61.2 per cent of global employment: ${ }^{2}$

The proportion of informal employment varies in different regions. Among the five main regions, the vast majority of employment in Africa (85.8 per cent) is informal. Asia and the Pacific (68.2 per cent) and the Arab States (68.6 per cent) have almost the same level of informality. In the Americas (40.0 per cent) and Europe and Central Asia (25.1 per cent), less than half of employment is informal. Excluding agriculture, the global level of informal employment falls to 50.5 per cent, but non-agricultural informal employment remains high in three regions (Africa, the Arab States, and Asia and the

1 This part relies partly on Olivier, Andrianarison and McLaughlin (2013).

2 ILO (2018), references omitted. 
Pacific). Emerging and developing countries have higher shares of informal employment than developed countries. Emerging and developing countries represent 82 per cent of world employment, but 93 per cent of the world's informal employment is in these countries.

Those involved in agriculture, women, the young and the old, as well as those with no education and living in rural areas, are in particular affected. ${ }^{3}$

The lack of social protection is one key characteristic of the informal economy, as are low productivity, poor working conditions and an absence of legal protection and rights. It has been suggested that: ${ }^{4}$

The two main categories of informal employment, wage employment in jobs without social protection and self-employment in unincorporated enterprises, can be further disaggregated into different categories of employment relationships. Self-employment consists of own-account workers and employers of informal enterprises who hire other workers. The conditions of these two categories are often very different. Wage-employment includes informal employees of both formal and informal firms, subcontracted workers, wage workers for households (domestic workers), and wage workers with no fixed employer (casual day workers).

While this distinction is valid, it needs to be said that there is a vast and growing range of other forms of work which cannot be regarded as either self- or wage employment, but which are also associated with the absence of or weak social security protection. Many of these (informal) workers do their work in supply chain contexts, and may not have a relationship with an employer, but at best with a "provider" of work. Others may be working in the care economy, and could hardly be regarded as being self-employed in the sense used above. ${ }^{5}$

In fact, one should be careful to rely on standard classifications in this area; as has been noted: "Informal sector heterogeneity continues to defy easy generalizations." 6 In their 2012 contribution, based on a representative sample from seven capital cities in francophone West Africa, Grimm, Knorringa and Lay commented on the needs experienced by a sizeable group of informal economy entrepreneurs, who generally lack access to capital, insurance and productive infrastructure. Appropriate social protection policy interventions would therefore require addressing these

3 ILO (2018) pp. 20, 26, 29-30.

4 EC (2012). See also Lund (2012).

5 See also Lund and Srinivas (2000).

6 Grimm, Knorringa and Lay (2012) p. 28. 
shortcomings, including the provision of insurance to cover important household-related risks, such as health shocks and death. ${ }^{7}$

Also, the borderlines between formal and informal have increasingly become fluid and blurred as formal employment has decreased worldwide, and as people tend to move out of formal into informal and non-traditional employment, and vice versa, more readily than in the past. There is, therefore, both a continuum and a fluidity or mobility between the formal and informal economy. ${ }^{8}$ This may make the development of suitable social security responses exceptionally complex.

Different from what the position might be in the so-called developed economies, informal employment is not generally regarded as illegal or irregular in the developing world, but as a standard way of life and income-generation. ${ }^{9}$

\section{LIMITED ACCESS TO CONTRIBUTORY AND NON-CONTRIBUTORY SOCIAL SECURITY ARRANGEMENTS ${ }^{10}$}

Informal economy workers' limited access to social insurance and social assistance arrangements partly emanates from the very concept of social security as it has found its way into national legal systems and policy frameworks, and largely also in international and regional instruments. Traditionally, as is the case with social security schemes established in most developing countries, the social security concept draws a relatively strict distinction between formal employment-based social insurance and poverty-related social assistance instruments. ${ }^{11}$ Social insurance instruments rarely apply to informal workers, ${ }^{12}$ while social assistance arrangements are often, in developing countries, restricted to specific categories of vulnerable persons (the old, the young and the disabled) and therefore not available to the majority of informal workers. As a result of this, and the inherent bias towards the formal economy, social security systems

\footnotetext{
Grimm, Knorringa and Lay (2012) pp. 27-28.

Barrientos and Barrientos (2002) pp. 18-19; Fudge (2012) pp. 7-8.

9 Lund (2012) p. 13-14.

10 Adapted from Olivier, Andrianarison and McLaughlin (2013).

11 ILO (1989) pp. 3-5; Pieters (1993) p. 5.

12 Subject to some exceptions, social insurance laws essentially cover those in the formal economy, who work within the framework of an identifiable employment relationship: ILO (2008) p. 19.
} 
reach only a small percentage of the population in developing countries. ${ }^{13}$ As noted by Meknassi: ${ }^{14}$

... Yet both the potential offered by and the needs of informal and small-scale activities remain excluded from any organized social protection. Social security law places them on the margins of a legal and institutional framework that is designed exclusively for the industrial economy. It could not be extended to the majority of workers without root and branch reform, given the predominance of 'atypical' forms of work and pay.

Secondly, the nine (ILO-indicated) traditional categories of contingencies, ${ }^{15}$ including among others retirement, sickness, unemployment, employment injuries and diseases and maternity, which essentially inform international and regional social security standards and which form the basis of social security schemes in many developing countries, are largely incompatible with the realities in these countries. ${ }^{16}$ While these risk categories may be helpful in identifying more common life experiences and the situations to which human beings are generally exposed, they are not suited to extending social security to informal economy workers also because they prioritise state-regulated and formal social security as opposed to non-formal and non-state-regulated social security arrangements which service the majority of the workers in the informal economy. As noted by a renowned Indian scholar working in this area, Professor Kamala Sankaran: ${ }^{17}$

The economic right to obtain gainful employment with the safety net provided by social security in the form of income security and health benefits has been at the center of the social security systems in the developed world. Over the last thirty years this paradigm of social security has been increasingly questioned, and an alternative conception of preventive and promotional forms of social security has been put forward. Economic security has usually meant the maintenance of existing levels of income. For the self-employed in the informal economy, the loss of assets, loss of access to markets, and exposure to risks are often reasons for their economic insecurity. A comprehensive right to economic security as a form of social security would require a comprehensive safety net against such risks.

\footnotetext{
13 Olivier (2009) pp. 3-4.

14 Meknassi (2006), p. 214.

15 See ILO Convention 102 of 1952 on Social Security (Minimum Standards).

16 Jutting (1999) p. 2.

17 Sankaran (2012a), pp. 89-90 (emphasis added).
} 
Thirdly, the risks enumerated in the ILO definition are individual-centred, concentrating on protecting the individual from insecurity that may affect him or her. They largely ignore the common collective risks which normally befall informal economy workers in many developing countries such as war, crop failure, natural disasters and other calamities. ${ }^{18}$ And yet risks such as these experienced by people in the developing world are often of a collective and covariate nature, ${ }^{19}$ and require interventions that go beyond traditional individual-oriented social security responses.

In the fourth instance, there is a wrong presumption that the members of society have already reached an acceptable standard of living which has to be protected. ${ }^{20}$ The reality in developing countries, Africa in particular, indicates that the majority of people live in abject poverty and they need to be uplifted to an acceptable standard of living. ${ }^{21}$

As a fifth consideration, the reach of international standards remains limited. Apart from the fact that the ratification record of developing countries as regards ILO social security standards is exceptionally limited, with some exception, it can hardly be said that these standards were generally developed with the informal economy in mind.22

Finally, informal workers may be excluded from coverage because: 23

- a national social insurance scheme covering a particular benefit such as pensions - does not exist, while participating in the private or occupational scheme alternatives may not be affordable for or otherwise attractive to informal workers;

- informal workers may not be compelled to take up membership of an existing national scheme; or

- little incentive exists to join a scheme which may be open to informal workers - this may be the result of the fact that

o (self-employed) informal workers are often required to pay a double contribution, ${ }^{24}$ or

18 Olivier (2011) p. 424; Jutting (1999) p. 2.

19 Holzmann (2002) par III; Olivier (2011) p. 424; Jutting (1999) p. 2.

20 Olivier (2009), p. 5.

21 Kaseke (2005) p. 91.

22 Meknassi (2006).

23 Olivier (2011).

24 This applies in particular to sub-Saharan countries (e.g. Ghana (in terms of earlier arrangements), Namibia, Rwanda, Tanzania and Zambia). 
o informal workers who employ others may be barred from participating in a social insurance scheme, ${ }^{25}$ and

o no incentives to join a national scheme, in the form of flexible contribution modalities and targeted or tailor-made benefit packages exist.

Overall the effect of all of the above is that dealing with and managing the risks to which informal economy workers and their dependants are exposed, due to the absence of labour law and social security protection, are effectively shifted onto such workers and their families, and ultimately to other social security schemes (such as health care schemes) and state-provided social assistance. A pronounced focus on social protection interventions which recognise the context of informal workers as (category/categories of) workers in need of protection is required suggesting that formalisation of informal workers/informal activity will provide appropriate responses may be unrealistic, as the tendency in many parts of the developing world is towards increased informalisation. ${ }^{26}$

\section{COMPARATIVE EXPERIENCES ${ }^{27}$}

Comparative developments indicate that several innovative attempts have been made, especially in recent years, to extend coverage to informal workers in developing countries. ${ }^{28}$ The attempts embrace both conceptual and regulatory developments, institutional initiatives, as well as tailormade design options. In addition, supportive arrangements, including a focus on stakeholder consultation, communication and an informal sector-friendly enabling framework, are important. These developments discussed below cover employment-related protection, that is, that part of the system mainly captured by contributory arrangements, as well as social assistance provisions. 1994.

25 See, for example, section 20(2) of the Namibian Social Security Act,

26 See, among others, Lund (2012); for the statistical picture, see ILO (2018) 13-14.

27 See also Olivier (2017).

28 See in particular Olivier (2014). 


\subsection{Conceptual and Regulatory Developments}

Some countries have addressed exclusion by redefining the concept of employee/worker in legislation governing social security coverage. ${ }^{29}$ Developing countries are increasingly seeking innovative conceptualisation to widen the application of social security beyond the traditionally envisaged groups. In India, for example, in an attempt to ensure social security provision for the huge informal economy, the Unorganised Workers' Social Security Act (Act 33 of 2008) adopted a deliberately extensive notion of what is comprehended by the term "unorganised sector", and of who is intended to be an employer and a worker for the purposes of covering those embedded in a relationship of work in the informal economy. ${ }^{30}$ Corresponding innovations are also found in some countries. In Tanzania, the Social Security (Regulatory Authority) Act, defines the "informal" as the sector that includes workers who work informally and who do not work in terms of an employment contract or another contract contemplated in the definition of employee. ${ }^{31}$ The definitional extension could also occur on an industry basis. For example, in the beedi industry (hand-rolled cigarettes), the Beedi and Cigar Workers (Conditions of Employment) Act in India ${ }^{32}$ covers a person employed directly or through any agency who is given raw materials by an employer or a contractor: in this way, outworkers and home workers are included. ${ }^{33}$

In a range of developing countries, labour laws (which often have social security consequences as well), achieve extended protection through a deliberate widening of the employee concept. In Swaziland, for example, an "employee" includes a person who works for pay or other remuneration not only under a contract of service but also "under any other arrangement involving control by, or sustained dependence for the provision of work upon, another person". ${ }^{34}$ Similar developments have been discerned in Caribbean countries. ${ }^{35}$

Innovative conceptualisation is an area that lends itself to significant further development. For example, adopting appropriate regulatory techniques to comprehensively cover supply chain scenarios would support

\footnotetext{
29 See Olivier (2014), on which the rest of this sub-paragraph is based.

30 Unorganised Workers' Social Security Act (Act 33 of 2008), section 2(k).

31 Social Security (Regulatory Authority) Act 8 of 2008, section 3.

32 Act 32 of 1996.

33 Sankaran (2012a) p. 44.

34 Swaziland Industrial Relations Act 1 of 2000.

35 Taylor (2003).
} 
extension of protection, ${ }^{36}$ while a widening of the "trade union" membership concept in the legal systems of many developing countries (currently usually restricted to employees only) would enable trade unions to officially represent informal worker members.

\subsection{Institutional Initiatives}

Note should further be taken of institutional initiatives which have occurred world-wide. Developing countries have been adopting a wide range of complementary mechanisms to effect coverage extension to excluded categories, impacting in particular on self-employed and informal workers. ${ }^{37}$

- Extending the reach of social assistance arrangements: ${ }^{38}$ In the search for effective poverty alleviation and sustainable development measures, several middle-income countries have introduced largescale non-contributory programmes that transcend the concept of residual social assistance schemes, such as the Bolsa Familia and similar schemes in Brazil, Opportunidades in Mexico, and the social assistance grant system in South Africa, covering almost one-third of the population. Similarly, the Chinese Di-Bao programme is the largest unconditional cash transfer programme in the world, reaching about 78 million individuals. ${ }^{39}$ The direct and distributional impact of these programmes has reportedly been comprehensive, as they are invariably linked with complementary social welfare programmes, and thus successfully address poverty at the individual and household levels, enhance educational, food and health care access and promote entrepreneurial activities. ${ }^{40}$

Elsewhere, especially in most Asian and African countries, until recently, social assistance interventions have been weakly developed. And yet, means-tested and universal programmes have increasingly been established for certain risk areas, particularly

36 Lund (2012) pp. 23-24. Important developments in this area have occurred in developed countries' jurisdictions, such as Australia, although even here the developments are still piecemeal and sector-focused: see Rawling (2006).

$37 \mathrm{Hu}$ and Stewart (2009). See generally Olivier (2014), as well as Olivier, Andrianarison and McLaughlin (2013) pp. 81-82.

38 See Olivier (2014), on which the rest of this sub-paragraph is based.

39 World Bank (2014) p. 11.

40 OECD (2009) pp. 24, 31; Woolard and Leibbrandt (2011). 
pensions, for example, in Nepal and Namibia. ${ }^{41}$ Given their universal focus, they are accessible to informal economy workers as well. To this should be added the recent focus on introducing cash and conditional cash transfer schemes even in poor countries, often on a pilot basis, with a view to transforming these into scaled-up programmes, for example in several sub-Saharan African countries. ${ }^{42}$ And yet, as suggested above, these social assistance arrangements are often restricted to certain categories of persons only and are, therefore, not generally of benefit to informal workers.

- Extension of existing schemes to the informal sector, and making participation compulsory: In some cases existing contributory schemes have been extended to include at least some informal worker categories. For example, unemployment insurance and labour law arrangements (impacting on social security as well) have been extended to domestic workers in South Africa. ${ }^{43}$ Of particular importance is extension of coverage on a compulsory basis to the self-employed, in particular in several Latin American countries, but also in the Philippines. ${ }^{44}$ Traditionally, in developing countries, there was little incentive for the self- and informally employed to join existing contributory schemes, which were accessible to them on a voluntary basis. In an attempt to increase coverage, certain Latin American countries have commenced making participation in these schemes compulsory, supported by incentives such as eligibility for/access to other social security benefits (for example, family allowances) and lowering the contribution rate

41 Samson (2012) "Nepal".

42 Monchuk (2014); Olivier, Andrianarison and McLaughlin (2013) pp. 30-31.

43 Lund, (2012), p. 26; Olivier (2009) pp. 23-27.

44 Regarding the Philippines, see MacKellar (2009) pp. 26-28. MacKellar remarked (on p. 27): "The new social security law enacted in 1997 mandated compulsory social security coverage of self-employed persons, regardless of their trade, business or occupation, with an income of at least 20.1 USD a month and not over 60 years old. As a result, the coverage of informal sector workers has tripled over the last 10 years, from 1.7 million in 1997 to 5.6 million as of September 2006. As of June 2006, out of the 26.5 million individuals that were registered with the social security system in the Philippines, around $21 \%$ were informal sector workers, up from $8.8 \%$ in $1997 . "$ 
for low-income self-employed persons. ${ }^{45}$ As remarked by MesaLago, ${ }^{46}$ the few Latin American countries that require compulsory membership have better and more effective coverage.

- Embracing the whole informal economy: Some governments have extended existing arrangements to the entire informal market. India ${ }^{47}$ and Indonesia ${ }^{48}$ are examples of countries that adopted overarching framework legislation aimed at extending social protection to the whole of the informal economy and to informal workers generally. Also, establishing universal schemes has become the hallmark of achieving extended coverage. Risk-category schemes based on a dedicated legal mandate and/or policy framework have been introduced, including universal health insurance schemes in Ghana, Rwanda and Thailand ${ }^{49}$ among others and, as indicated later in this contribution, comprehensive pension schemes have been introduced for rural and urban workers in China. ${ }^{50}$ All of these schemes have achieved remarkable coverage in a short space of time.

Another example of this approach concerns the creation of targeted schemes for informal workers. The Ghana Informal Sector Fund $^{51}$ and the Kenya Mbao Pension Scheme ${ }^{52}$ serve as useful

45 For example, in Chile the self-employed were meant to be fully mandatorily included in the national pension system by 2015 , and in the health system as from 2016: see Mesa-Lago (2008) p. 394; see also Calvo, Bertranou and Bertranou (2010) p. 230.

46 Mesa-Lago (2008) p. 389.

47 Unorganised Workers' Social Security Act, Act 33 of 2008. See also par 5.2 below.

48 National Social Security Law of Indonesia, Act 40 of 2004.

49 Regarding Thailand, see Damrongplasit and Melnick (2009) p. 457; Olivier (2009) pp. 27-29. Other African countries that have decided to go this route (although implementation may still be absent, or not fully realised) include Benin, Côte D'Ivoire, Gabon and Nigeria.

50 The voluntary rural and urban pension schemes were introduced in 2009 and 2011 respectively, and are (co-)funded by government via matching contributions. By the end of the first quarter of 2012, 376 million people were already participating in the two schemes, despite weak incentives to contribute above the minimum (see Dorfman, Wang, O'Keefe and Cheng (2012); Servais (2012), p. 14). See also par 5.1 below.

51 Informed by an extensive consultative process initiated by a presidential commission, the Fund provides for flexible contribution modalities and a two-tier tailor-made benefit arrangement, which ensures both long-term benefits and the opportunity to utilise funds for a range of core needs; in a short space of time 90,000 informal workers have joined the Fund (Olivier, 2009). See par 5.4 below.

52 Njuguna (2012) pp. 86-88. 
examples, having attracted (also as the result of informal workerssensitive design features) sizeable memberships in the few years since they were established.

- Adopting a sector-by-sector-approach: In some countries informal workers have been included sector by sector, usually on the basis of separate or dedicated schemes. Rather than attempting to solve the problem on an informal economy-wide basis, policymakers have chosen key sectors to increase coverage. One example is the welfare funds established in India. They are financed through levies collected from selected employers and manufacturers, ${ }^{53}$ and provide a range of benefits, including social security-related benefits such as medical care and maternity assistance. Also at a state level, a tax (cess) is imposed by state governments on the aggregate output of selected industries (for example, the Beedi Welfare Fund is financed by a tax on beedis). ${ }^{54}$ Another prominent example is the establishment of gradualist sector-by-sector schemes embedding tailor-made solutions, provisions and prescriptions for particular groups of workers in the informal economy in Tunisia. This latter approach is among others based on the introduction of realistic income scales which determine the lowest income bracket (for purposes of contributions) relevant to the occupation of the insured person (physician, architect, shopkeeper etc.) and the size of the firm or farm, supported by educational and promotional programmes regarding the value of income protection. ${ }^{55}$ Sector-based approaches have also been used in South Africa's domestic worker environment.

- Self-initiated and government-supported arrangements for specific beneficiary groups: Approaches to benefit specific beneficiary groups may have a home-grown basis - as is the case with the Self Employed Women's Association (SEWA) in India, which arranges among others social security protection for its 1.33 million members in the informal economy. Operating both as a trade union and cooperative, and through its links with formal insurance schemes, SEWA has managed to provide its members with wide-ranging services including credit, training, child care, health care, pension, life insurance (death and disability) and insurance against loss of work equipment; it has become an influential actor at both the

53 Lund (2012) p. 23.

54 Olivier (2009) p. 15.

55 Chaabane (2002). See par 5.3 below. 
national and international level.56 In Tanzania, a hybrid model is being implemented through the Community Health Fund (CHF), a voluntary government-introduced insurance-based hybrid scheme administered at district level and co-financed by the community (household) and the government. ${ }^{57}$

- Micro-health insurance schemes: Micro-health insurance schemes exist in many (West) African and Asian countries. However, due to lack of scale and other reasons few of these arrangements seem viable, unless they are consolidated and eventually linked to national initiatives. This is apparent from envisaged interventions in Senegal, and the recent experience of Ghana and Rwanda. ${ }^{58}$

\subsection{Tailor-made Design Modalities}

Design characteristics, in the form of specialised contribution modalities, relaxed entitlement criteria and context-sensitive benefit packages, for the informal economy as a whole, or for particular sectors, have assisted in addressing the challenge as to why informal workers were unwilling, if not unable, to participate in the past. ${ }^{59}$ Contribution modalities include: (1) allowing informal workers to contribute to the extent of their ability at a frequency that suits their particular context and contributory capacity, for example in Ghana and the Philippines; ${ }^{60}$ (2) adopting realistic income

\footnotetext{
56 Lund (2012) pp. 21-22; Routh (2013) pp. 15-17.

57 Mtei and Mulligan (2007) p. 2.

58 Olivier (2009) pp. 11, 29, 34-35; see also WHO (World Health Organization) (2010), pp. 12-14.

59 See Olivier (2009) pp. 15-17; Servais (2012) p. 4.

60 Regarding Ghana, this is provided for within the framework of the Ghana
} Informal Sector Fund, referred to above and in par 5.4 below. In the Philippines, in addition to compulsory arrangements, the Philippines Social Security System has adopted several flexible approaches to meet the requirements of informal sector workers who do not have access to formal banking arrangements and who are only able to contribute irregularly, by introducing the following programmes and (in the process) partnering with organised informal sector groups (ISGs) and Local Government Units (LGUs) (see Mines (2015)):

1) AlkanSSSya Program for the self-employed in the services sector;

2) Servicing and/or Collecting Partner Agent Agreement for cooperatives and microfinance institutions;

3) Contribution Subsidy Program for farmers and workers in the agricultural sector; 
baselines for the calculation of contributions, for example in Tunisia; and (3) topping up small contributions of poor workers by way of government subsidies, for example in India ${ }^{61}$ and Tanzania. Relaxed entitlement criteria allow informal workers to access benefits without complying with lengthy periods of contribution or other onerous conditions. Dedicated, context-sensitive benefit arrangements are addressing the key short- and long-term needs of informal workers. They may not include all the traditional social security benefit categories, but simultaneously provide for the use of benefits towards other core needs, such as education.

\subsection{Supportive Arrangements: Consultation, Communication and an Enabling Framework}

Extending coverage to and enhancing social security-related protection of the informally employed cannot be achieved in isolation. It is suggested that there are at least three areas of intervention that are required to ensure that a suitable context of coverage and protection is in place.

- Stakeholder consultation: Firstly, there is need to ensure that appropriate stakeholder consultation takes place, to determine concrete options - and consider challenges and solutions - in relation to extending coverage to the informally employed and developing suitable protection modalities for them.

Relevant options, dealing among others with appropriate contribution rates and payment modalities, eligibility criteria and dedicated benefit regimes, have to be considered and, once revised and adopted, submitted for implementation. World-wide experience has shown that successful coverage extension and suitable forms of protection in social security terms for those who work informally have been preceded by thorough consultation with stakeholder groups and institutions.

Also, while consultation would have to involve the targeted groups themselves, at times even at grass-roots level, the consultative team itself has to have a high-level status, and preferably

4) Coverage Program for government job order and contractual (JO/C) workers; and

5) MuniSSSipyo-Collect Program for unbanked areas or provinces.

61 Both the Union Government and State Governments in India contribute comprehensively to top up small informal worker contributions in relation to social security schemes which focus on including informal workers: see among others Dorfman et al. (2013) pp. 99, 125. See also par 5.2 below. 
reflect stakeholder group representation. In some countries the introduction of suitable arrangements for covering the informally employed was preceded by a thorough consultative process conducted by a presidential ${ }^{62}$ or government-appointed ${ }^{63}$ commission.

- Communication: Secondly, as supported by evidence emanating from other countries where the self- and informally employed have been included in social security schemes, there has to be thorough communication of envisaged new arrangements. In particular, those who are affected by the new arrangements, including informally employed workers and, where relevant, their providers of work, have to be properly informed. Given the national relevance of such arrangements, awareness-raising interventions targeting the general public also have to be introduced.

- Enabling framework: Thirdly, extending coverage and enhancing protection would require that a proper enabling framework has been established and is operational. The meaningful participation of the informally employed implies that they should be supported to do so - from both a broader policy and operational perspective they have to be strengthened and enabled.

Among others, steps that would enhance the ability, in particular of those operating and working in the informal economy, to contribute to and access the new system have to be considered and introduced. Fixing the minimum wage at a level that would enable them to contribute would be one such matter to be considered.

In addition, those operating in the informal sector are in need of access to credit, tailored banking services, transport, training and skills development packages, mentoring and appropriate business opportunities. Some of these matters are currently being addressed in, for example, the Indian context - among others through the linking of the so-called Aadhaar biometric identification card facility to bank accounts in order to enhance financial inclusion. Also, overcoming supply- and demand-side constraints, and access to markets are some of the core priorities to be addressed.

In essence then, government and other stakeholders would have to play a crucial promotional and development role to support those involved in the informal economy and enhance their capacity to participate meaningfully in the reformed social security framework. Of course, it is necessary to consider and weigh up costs and

\footnotetext{
62 E.g. Ghana.

63 E.g. India.
} 
benefits. A government has to prioritise actions and spending and ask where the attention should most crucially be focused.

\section{SELECTED COUNTRY CASE STUDIES}

\subsection{Extension of Social Protection to Informal Workers: China ${ }^{64}$}

The informal sector in China is considered as one of the main driving forces beyond economic growth in China. This heterogeneous sector is highly mobile, dynamic and competitive, and has close links with internal migration. Its growth in China has been associated with several factors, including economic restructuring, rural-urban migration, labour market segmentation, weak formal safety nets and a social protection system which incentivises informal sector growth. 65

In 2007, an Organisation for Economic Co-operation and Development (OECD) study noted that, depending on the definition used, even in urban areas in China informal work constitutes 50 per cent of all urban employment, fuelled in particular by internal migration. ${ }^{66}$ However, more recent data indicate that the share of informal employment has been decreasing rapidly, from a high of 65.2 per cent in 2001 to 40.3 per cent in 2010 - this is largely due to China's economic growth, marketoriented reform and labour market regulation, which effectively extended labour (law) protection to more informal workers. ${ }^{67}$ Migrants account for more than one-third of urban workers, ${ }^{68}$ thereby contributing to the shared fate of internal migrants (also migrant workers) and informal urban workers for social security coverage purposes. In fact, these categories remain poorly covered in terms of retirement-related social insurance provisioning. Poor coverage is the result of several overlapping factors, in particular: ${ }^{69}$

- the occupation-oriented nature of public pension scheme coverage;

- the lack of enforcement of labour regulations;

\footnotetext{
64 See Olivier (2017) from where this has been taken.

65 See Jütting and Xenogiani (2007).

66 Ibid.

67 See Gao (2015); Yang (2010).

68 Gao (2015).

69 Jiang, Qian and Wen (2018).
} 
- the voluntary nature of membership of urban (and also rural) pension schemes for urban and rural residents respectively (as opposed to workers, who are compelled to enrol);

- self-selection, as a result of the fact that: (1) even those who opt out of social insurance coverage remain covered under the basic social assistance programme (e.g. the Minimum Livelihood Guarantee Scheme (Di Bao)); and (2) employers are more likely to opt out, as they think that the social insurance programmes emphasise redistributive functions and provide unattractive benefits.

In addition, the inability of migrant workers who are not registered to work in cities, due to the operation of the Hukou system, further contributes to the absence of formal social protection. ${ }^{70}$

Informal workers are therefore served by old age-related social insurance schemes only to a limited extent, particularly in rural areas, and as they do not generally participate in urban old-age insurance systems. ${ }^{71}$ In fact, as has been indicated, the weak social protection position of informal workers, in particular migrant workers, also extends to their family members, many of whom remain in rural areas. ${ }^{72}$

Nevertheless, important changes to this scenario are discernible, mainly for two reasons. Firstly, the Chinese government has strengthened labour market regulations, as is apparent from the range of new labourrelated laws that have been enacted: it seems that stricter regulations have positive effects on increasing coverage rates. Secondly, the changes in main labour market outcomes (e.g. increased formal employment and increased earnings for unskilled workers) facilitate the improvement in coverage modalities. ${ }^{73}$ Despite this, a considerable wage gap still exists between informal and formal workers, which enhances labour income inequality in urban areas: a recent study indicated that informal employees' earnings were 67 per cent of those of formal employees, and this large earnings gap raised the Gini coefficient to 0.42 in $2005 .{ }^{74}$

One of the critical tasks ahead is to take steps to reduce and overcome the inherited inequality. From a social protection perspective, also as far as social insurance-based retirement provisioning is concerned, it appears

\footnotetext{
70 Jütting and Xenogiani (2007).

71 Dorfman et al. (2013) pp. 3-4, 26, 35; see also Jütting and Xenogiani (2007).

72 Jütting and Xenogiani (2007).

73 Yang (2010).

74 Gao (2015).
} 
necessary to take steps to integrate different components of the system. ${ }^{75}$ The envisaged unification of public urban and rural pension systems, and the granting of urban residence permits to an increasing number of permanent urban residents are important steps towards integration, equal treatment and extended coverage. ${ }^{76}$

\subsection{Comprehensive and Innovative Arrangements in India}

\subsubsection{Background}

Despite attempts over several years by Central and State governments to extend social security coverage to marginalised groups of workers, the current state of affairs is still wholly unsatisfactory. In a study undertaken for the ILO, Srivastava (2013) indicates: ${ }^{77}$

- only 1 per cent of agricultural workers reported coverage in terms of employer-arranged social security in the form of a provident fund scheme;

- almost the entirety of casual workers did not avail of any social security benefit, while the share of those receiving at least one benefit among regular workers was only 55 per cent; only about one-fourth of regular workers had all three benefits (Provident Fund/Pension; Gratuity; Health care and maternity benefit);

- wage workers in the unorganised sector too had almost no social security benefit, except 1 per cent who had access to a provident fund/pension benefit. Even within the organised sector, nearly 33 per cent had all benefits and 10 per cent had access to a provident fund/pension benefit, while 47 per cent were not eligible for any benefit.

By 2010, the percentage of all wage workers covered under any social security provision had declined from 32.6 per cent in 1999-2000 to 28.6 per cent in 2004-2005 and further to 26.4 per cent in 2009-2010. This coincided with a casualisation of the workforce and the increased informalisation of regular employees in the government sector and in public limited companies. ${ }^{78}$ According to the 2016 Economic Survey, the share of informal employment in the organised sector had increased from

\footnotetext{
75 Yang (2010).

76 See Olivier (2017) for further details.

77 Srivastava (2013) pp. 21-22.

78 Id., pp. 22-23.
} 
48 per cent to 54.6 per cent from 2004-2005 to 2011-2012. ${ }^{79}$ Srivastava further referred to the estimates of the National Commission for Enterprises in the Unorganised Sector (NCEUS) regarding coverage of workers in the unorganised sector, indicating that the Commission's estimates showed that the existing models covered only a small proportion around 8 per cent - of the country's vast army of informal workers. ${ }^{80} \mathrm{He}$ concludes as follows: ${ }^{81}$

Our brief review shows that governmental and non-governmental initiatives to address the social security needs of the working poor in India are woefully inadequate. In the organized sector, the proportion of workers covered has fallen due to informalization of the workforce. The poor, who eke out an existence through various types of informal employment in the unorganized sector, are among the most vulnerable in any society. A shock that has a relatively small impact on the non-poor can be a cause for great concern for the poor, since even marginal downward fluctuations in income can push them to destitution levels. Social security measures which address the contingent risks faced by them are woefully inadequate, except in certain parts of the country.

\subsubsection{Recent developments - framework provided by the Labour Code on Social Security}

The recently published 2018 Draft Labour Code on Social Security ${ }^{82}$ (hereafter referred to as the Draft Code), prepared by the Ministry of Labour and Employment, Government of India, aims specifically at extending coverage of social security to informal economy workers. This follows an earlier largely unsuccessful legislative attempt to achieve such coverage extension. The Draft Code evidently foresees extensive coverage of those who work in the informal economy. This appears from the following:

- Comprehensive sphere of application: The Draft Code is said to apply among others to all "entities" as well as to "workers that are employed by any entity" as well as a worker "who may also be the

\footnotetext{
79 Ministry of Finance, GOI (2016).

80 Id., p. 25.

81 Id., pp. 25-26.

82 See the Draft Code of March 2018, published on the website of the Government of India's Ministry of Labour and Employment - http://www. labour.nic.in/sites/default/files/draft\%20Labour\%20Code\%20on\%20Social\%20 Security\%20\%26\%20Welfare.pdf, accessed on 2 November 2018.
} 
owner or the proprietor of an entity or a self-employed unit" (see clauses 1.4 and 1.5).

o Extended application is achieved on the basis of the wideembracing scope of both the concepts of "entity" and "worker", in addition to use being made of a distinction between "organised sector" and "unorganised sector" (see below).

o "Entity" is defined with reference to both an "enterprise" and a "household". 83 "Enterprise" includes a project, undertaking or business carried out also by a cooperative society, a self-help group, and an association of persons or body of individuals whether incorporated or not. "Household" in turn denotes "a group of occupants or a family regarded as a unit including individuals who comprise a family unit and who live together under the same roof, dwell in the same place, and are under control of one domestic head" 85 - the household may or may not encompass domestic help.

o The "worker" concept is cast deliberately wide to encompass as wide a range of people who work as possible. This term is defined to include a person who performs work for an entity, or who provides services, whether regular or part-time to an entity, whether directly or through an agency, for wage, profit or gain, in cash or kind, whether under a contract of employment, or other contract where an individual undertakes to do or to provide personally the work or services, whether the contract is expressed or implied. The term is said to include all employees of an entity irrespective of the nature of work performed by them and, importantly, persons performing voluntary services for an entity and receiving honorarium shall be deemed to be workers. ${ }^{86}$

o The term "worker" explicitly includes both "an employee" and "a non-employee". 87 "Employee" is an extensive concept, even though it is "limited" with reference to the requirement that wages must be earned by the person so employed by an entity. Nevertheless, this term encompasses all kinds of employment

83 Clause 2.46 .

84 Clause 2.45.

85 Clause 2.58. See also clause 2.43, which defines "employer" also with reference to the head of a household, in the case of a household or an enterprise undertaken by a household.

86 Clause 2.140.

87 Ibid. 
contracts and includes among others extensively formulated employee categories, such as a part-time worker, a piece rate worker, an outworker, a seasonal worker, a domestic worker and a home-based worker. ${ }^{88} \mathrm{~A}$ "non-employee" comprises a "selfemployed worker" and an "owner-cum-worker". ${ }^{99}$ The definition of "owner-cum-worker" is crafted in a way that includes a person who simultaneously works in two capacities - as owner, head or proprietor and as worker, in that establishment. ${ }^{90}$

o "Unorganised sector" is defined to mean (1) establishments which employ workers, and the number of such workers is less than the threshold; (2) own account enterprise; and (3) households that employ domestic workers for carrying out the activities of the household. ${ }^{91}$

- The extensive categories of persons covered by the "worker" concept is then used, at least partly, as a basis for formulating registration and contribution-paying obligations. Registration of workers will be effected in any of the different categories; there is a general obligation on every worker to register/to be registered. ${ }^{92}$

- Contribution payment reflects and builds on the distinctions indicated above. Contributions are payable by employers and workers; ${ }^{93}$ provision is also made for government contributions, ${ }^{94}$ although not specified.

- Differentiated contribution payment obligations are imposed on workers depending on, in particular, the socio-economic category to which the worker belongs. No contribution is required by a worker who falls within the lowest socio-economic category. ${ }^{95}$

\subsubsection{Other specialised arrangements to achieve informal economy worker inclusion}

In serving the overarching goal that a transformed social security system should address the underlying structural and material basis of social exclusion, as well as multi-dimensional poverty, social security policy and system design should be sensitive to the fact that for informal

\footnotetext{
88 Clause 2.42 .

Clause 2.77 .

Clause 2.95 .

Clause 2.133 .

Clause 11.

Clause 20.

94 See in particular clause 25.1

95 Clauses 20.3 and 20.4.
} 
economy workers, meeting immediate needs, and not merely future contingencies, is a priority. ${ }^{96}$ Apart from the needed emphasis on sufficient health protection, there is evidently a need to provide for, and protect, the means by which informal workers earn a livelihood. It is significant to note that several Indian state governments (e.g. Karnataka and Odisha) make provision in their social security schemes for among others assistance for the purchase of working tools, which (at least in the case of Karnataka) has resulted in considerable take-up. ${ }^{97}$

\subsection{Tunisia: Social Security for Informal Economy Workers ${ }^{98}$}

Tunisia has employed an innovative gradualist approach that has achieved high levels of social security coverage, especially within the informal economy. In 1996, Tunisia implemented a social security system which combined proper enforcement with the creation of a more accurate income estimation system for the self-employed. These two aspects, combined with education programmes, have seen high levels of growth in coverage, with 80 per cent of Tunisia's employed population covered by some form of social security in 1999, in comparison to just 60 per cent ten years earlier. Coverage has been extended for health care, old age pensions, maternity and employment injury. The expansion of social security in Tunisia has been successful at targeting large portions of the informal economy, including: craftspeople, petty traders and small farmers although levels of coverage still remain low in these industries in comparison to other industries. The first part of the approach saw changes to the social security system, with new legislation enacted in 1995 which unified the two existing social security schemes - one for self-employed agricultural workers and one for self-employed nonagricultural workers. The two schemes had been differentiated by the scope and the amounts of benefits, the level of contribution rate and the basis taken for calculating contributions. The unification of the two schemes led to an increase in the amount of agricultural self-employed and an increase in the scope and benefits of the scheme. The second change to the system was the extension of the bracket on which the flat-rate income on contributions was calculated. To coincide with this, efforts were made to avoid minimal contributions by the self-employed based on the lowest income brackets. A realistic income scale which

96 Ahmad, Drezé, Hill and Sen (1991) p. 43.

97 In the case of Odisha, one of the schemes also provides for the purchase of a bicycle.

98 Chaabane (2002); Olivier (2009) (from where this part has been taken). 
determines the lowest income bracket relevant to the occupation of the insured person (physician, architect, shopkeeper etc.) and the size of the firm or farm was introduced. Through the application of this scale, each insured person must contribute equal to the bracket employed on the scale, unless they can prove that their real income is lower, while they are free to contribute on a higher scale. These changes to the social security system had a positive influence which resulted in coverage extension. Educational and promotional programmes have also coincided with a change in attitude by many Tunisians which has seen them embrace income protection for old age, and protection against illness as a priority. This change in attitude is borne out of rising medical costs, an educational role played by trade unions and the government, and positive experiences of the benefits of social security. These aspects have combined to legitimise social security. The new measures combined with the awareness and education campaigns had led to almost 70,000 new affiliations in 1996 and 1997 alone. However, the reforms to the social security system have not been successful in extending coverage to everyone in the informal economy.

\subsection{Ghana Informal Sector Fund ${ }^{99}$}

Ghana provides an illustration of an initially less than successful attempt to use an existing public fund to extend social security coverage to the informally employed. However, innovative measures were introduced in 2010 to cover informally employed workers. This entailed the creation of the Informal Sector Fund, and dedicated arrangements relating to both contributions and benefits. Contributions to this Fund need not be fixed, but could be based on their ability to pay on a basis preferred by them, be it daily, weekly, monthly, annually or seasonally. Informal workers contribute to two accounts: (1) a retirement account (to provide benefits on retirement); and (2) a personal savings account with rules for withdrawals before retirement (e.g. for education and business enhancement). Within three years since the establishment of this Fund, 90000 members have joined on this basis. It currently has 150000 members.

99 See Arku and Akagbo (2012); Adombila (2016). 


\section{CONCLUSIONS}

As indicated elsewhere, ${ }^{100}$ it is submitted that the political commitment which underlies the recent extension of social security entitlements to and coverage of those operating in the informal economy is reflective of economic considerations and shifting social, cultural and conceptual perceptions. Changing values in Asia, Latin America and Africa confirm a new appreciation of the import of social security, and the social contract between the state/government and its citizens, based on dialogue, serving the welfare interests of the people and moving away from an exclusive focus on economic growth; and a realisation that welfare enhancement is good for economic growth. ${ }^{101}$ Modernising society in emerging economies and its interest in appropriate social security arrangements imply that the state is no longer able to rely on the assumption that familial and community support would fill the void left by inadequate social security provision and regulation. Simultaneously these developments are seemingly informed by human rights considerations, which came to question increasingly the social security-concerned exclusion and marginalisation of the overwhelming majority of workers in most of the developing world.

The developments described in this contribution are indicative of a conceptual understanding and operational framework of social security which transcend traditional approaches and boundaries. And yet, challenges remain. One such area relates to the representative capacity of stakeholder institutions in the informal economy to exert appropriate influence on social security policy development to the advantage of informal workers. In this, the area of agency, voice and representation, there is some indication of innovative attempts to ensure that cooperatives, trade unions and other (often community-based) institutions represent the interests of informal workers. ${ }^{102}$ However, the efficiency of these interventions remains limited due to (at times) lack of scale, and the absence of recognition in the regulatory and policy realm of the status, role and capacity of these institutions - both in domestic and international systems.

A second challenge relates to identifying the workers concerned and their registration. Another concerns the determination of their income. And as already mentioned, a fourth challenge has to do with the need to

\footnotetext{
100 See Olivier (2014), from where this and the next paragraph have been taken.

101 OECD (2012).

102 Routh (2013), pp. 21-22; Fudge (2012), pp. 8-9, 21-22.
} 
involve, consult and liaise with these workers/persons - in the wake of weak representation and voice.

\section{BIBLIOGRAPHY}

Adombila, M "Contributions under SSNIT Informal Sector fund rises to GH $\$ 75 \mathrm{~m} "$ (22 June 2016), accessed at https://www.graphic.com.gh/business/ business-news/contributions-under-ssnit-informal-sector-fund-rises-to-gh-75m. html on 2 November 2018.

Ahmad, E, Drezé, J, Hill, J and Sen, A Social Security in Developing Countries (Oxford: Clarendon Press, 1991).

Arku, J and Akagbo, E “90,000 Join SSNIT - from the Informal Sector” (2012), accessed at http://www.graphic.com.gh/dailygraphic/page.php?news=14354 on 8 May 2012.

Barrientos, A and Barrientos, S Extending social protection to informal workers in the horticulture global value chain (Social Protection Discussion Paper Series No 0126, Washington, DC: World Bank report, 2002).

Calvo, E, Bertranou, F and Bertranou, E "Are old-age pension system reforms moving away from individual retirement accounts in Latin America?" Journal of Social Policy, 2010, vol 39(2) pp. 223-234.

Chaabane, M Towards the universalization of social security: The experience of Tunisia (Extension of Social Security, ESS Paper, no 4, Geneva: ILO, 2002).

Damrongplasit, K and Melnick, G "Early results from Thailand's 30-baht health reform: Something to smile about" Health Affairs, 2009, vol 28 (3) pp. 457466.

Dorfman M, Wang, M, O'Keefe, P and Cheng, J “China's pension schemes for rural and urban residents" in R Hinz, R Holzman, D Tuesta and N Takayaka (eds) Matching Contributions for Pensions (Washington, DC: The World Bank, 2012) pp. 217-241.

Dorfman, J et al. China's Pension System: A Vision (Washington, DC: World Bank, 2013).

EC (European Commission) Empowering people for inclusive growth: The perspective of the working poor in the informal economy (EC Concept Note High Level Panel, Brussels, 2012).

Fudge, J "Blurring legal boundaries: Regulating for decent work" in J Fudge, S McCrystal and K Sankaran (eds) Challenging the Legal Boundaries of Work Regulation (Oxford and Portland, Oregon: Hart Publishing, 2012).

Gao, W "Informal employment and its effect on the income distribution in urban China” (presentation, Brussels, 2015) Journal of Social Policy, 2015, vol 47 (2), accessed 2 November 2018 at file:///C:/Users/user/Downloads/Session\% 204\%20-\%20Gao\%20Wenshu\%20(1).pdf, pp. 335-357.

Grimm, M, Knorringa, P and Lay, J Constrained gazelles: High potentials in West Africa's informal economy (Working Paper No. 53, The Hague: International Institute for Social Studies (ISS), 2012). 
Holzmann, R "Risks and vulnerability: The forward-looking role of social protection in a globalizing world" in E Dowler and P Mosely (eds) Poverty and Social Exclusion in North and South (London and New York: Routledge, 2002).

$\mathrm{Hu}, \mathrm{Y}$ and Stewart, F Pension coverage and informal sector workers: International experiences (Working Papers on Insurance and Private Pensions, no 31, Paris: OECD, 2009).

ILO Introduction to social security (Geneva: ILO, 1989).

ILO Strategies to promote transition to formality in Africa (Contribution to the joint AU/ILO workshop on the informal economy in Africa, Dakar, 2008).

ILO Women and men in the informal economy: A statistical picture (3rd edn, Geneva: ILO, 2018).

Jiang, J, Qian, J and Wen, Z "Social Protection for Workers in the Urban Informal Sector in China: Institutional Constraints and Self-selection Behaviour" (2018), accessed at https://www.researchgate.net/publication/318831285_ Social_Protection_for_the_Informal_Sector_in_Urban_China_Institutional_ Constraints_and_Self-selection_Behaviour on 11 January 2019.

Jutting, J Strengthening social security systems in rural areas of developing countries (ZEF Discussion Papers on Development Policy, Bonn: Centre for Development Research, 1999).

Jütting, J and Xenogiani, T "Informal Employment and Internal Migration: The Case of China" (Beijing: OECD, Nov 2007), accessed at https://slideplayer. com/slide/8361611/ on 11 January 2019.

Kaseke, E "Social security and older people: An African perspective" International Social Work, 2005, vol 48 (1), pp. 89-98.

Lund, F "Work-related social protection for informal workers" International Social Security Review, 2012, vol 65 (4), pp. 9-30.

Lund, F and Srinivas, S Learning from experience: A gendered approach to social protection for workers in the informal economy (Geneva: ILO, 2000).

MacKellar, L Pension systems for the informal sector in Asia (Social Protection Discussion Paper, no 0903, Washington DC: World Bank, 2009).

Meknassi, R "Extending social security in the developing countries: Between universal entitlement and the selectiveness of international standards" Comparative Labor Law and Policy Journal, 2006, vol 27, pp. 207-223.

Mesa-Lago, C "Social protection in Chile: Reforms to improve equity" International Labour Review, 2008, vol 147 (4), pp. 377-402.

Mines, J "Moving toward inclusive growth: Philippine Social Security System" (Philippine Social Security System, 2015), accessed at https://www.sss.gov.ph/ sss/DownloadContent?fileName=2015_Updated_ISSA_Report_on_ISCoverage _FINAL.pdf on 11 January 2019.

Ministry of Finance, GOI Economic Survey 2016 (volume 1) (New Delhi: Ministry of Finance, Government of India).

Monchuk, V Reducing poverty and investing in people: The new role of safety nets in Africa (Washington, DC: World Bank, 2014).

Mtei, G and Mulligan, J Community health funds in Tanzania: A literature review (Dar es Salaam: Ifakara Health Institute, 2007).

Njuguna, A "Critical success factors for a micro-pension plan: An exploratory study” International Journal of Financial Research, 2012, vol 3 (4), pp. 82-97. 
OECD Promoting pro-poor growth: Social protection (Paris: OECD, 2009).

OECD Rethinking the welfare state: Asia's next revolution and Asian welfare states: New cradles to graves (The Economist, 8 September 2012).

Olivier, M Informality, employment contracts and extension of social insurance coverage (ISSA Project on 'Examining the existing knowledge of social security coverage', Working Paper, no 9, Geneva: International Social Security Association (ISSA), 2009).

Olivier, M "Informality, employment contracts and social insurance coverage: Rights-based perspectives in a developing world context" International Journal of Comparative Labour Law and Industrial Relations, 2011, vol 2 (4), pp. 419-433.

Olivier, M "Work at the margins of social security: Expanding the boundaries of social protection in the developing world" in W van Oorschot, $\mathrm{H}$ Peeters and K Boos (eds) Invisible Social Security Revisited: Essays in Honour of Jos Berghman (Leuven: Lannoo Publishers, 2014) pp. 215-230.

Olivier, M "Social protection innovation and challenges in China and Africa: Selected comparative perspectives" Frontiers of Law in China, 2017, vol 12 (3), September, pp. 429-472.

Olivier, M, Andrianarison, F and McLaughlin, M Study on social protection in Sub-Saharan Africa (Report commissioned by the European Commission, Brussels, 2013).

Pieters, D Introduction to the Basic Principles of Social Security (Deventer: Kluwer, 1993).

Rawling, M "A generic model of regulating supply chain outsourcing" in C Arup, P Gahan, J Howe, R Johnstone, R Mitchell and A O'Donnell (eds) Labour Law and Labour Market Regulation (Sydney: Federation Press, 2006).

Routh, A Forms of solidarity for informal workers in India: Lessons for future? (Paper presented at the Labour Law Research Network: Inaugural Conference, Barcelona, 13-15 June 2013).

Samson, M “Nepal senior citizens' allowance: A model of universalism in a low-income country context" in S Handayani and B Babajanian (eds), Social Protection for Older Persons: Social Pensions in Asia (Asian Development Bank, 2012) pp. 214-245.

Sankaran, K (2012a) "Flexibility and informalisation of employment relationships", in J Fudge, S McCrystal and K Sankaran (eds) Challenging the Legal Boundaries of Work Regulation (Oxford and Portland, Oregon: Hart Publishing, 2012) pp. 29-47.

Sankaran, K (2012b) "The human right to livelihood: Recognizing the right to be human" Comparative Labor Law \& Policy Journal, 2012, vol 34 (1), Fall, pp. 81-94.

Servais, J "The new ILO Recommendation on social security" E-Journal of International and Comparative Labour Studies, 2012, vol 1 (3-4), pp. 1-26.

Srivastava, R S A social protection floor for India (New Delhi: ILO, 2013).

Taylor, O "The Jamaican labour relations and industrial disputes act (LRIDA): A critical assessment" in N Cowell and C Branche (eds) Human Resource Development and Workplace Governance in the Caribbean (Kingston: Ian Randle Publishers, 2003) pp. 426-450. 
Woolard, I and Leibbrandt, M The role of cash transfers in reducing poverty and inequality in South Africa over the post-apartheid period (Unpublished paper produced for the National Planning Commission, Southern Africa Labour and Development Unit, University of Cape Town, 2011).

World Bank The state of social safety nets 2014 (Washington, DC: World Bank, 2014).

WHO (World Health Organization) "World health report 2010 - Health systems financing: The path to universal coverage (Executive summary)" (2010), accessed at http://www.who.int/whr/2010/10_summary_en.pdf on 11 January 2019.

Yang, D "Improving social protection system in China: Key trends and policies" (OECD, 2010), accessed at https://www.oecd.org/els/emp/45276885.pdf on 2 November 2018. 